\title{
Brzozowski and Cioran: The Legend of Young Poland and The Transformation of Romania
}

\author{
Andrzej Zawadzki
}

An attempt to compare Stanisław Brzozowski's and Emil Cioran's philosophies may seem initially surprising and not very promising. They belong to different generations (Cioran was born the year of Brzozowski's death in 1911) and, what is even more important, they dealt with different philosophical problems. For Polish readers, Cioran, as the author of Pe culmile disperārii (On the Heights of Despair), is first of all a historian of Western decadence and a perspicuous critic of the illusions inherent in the Western narrative of modernization. His works are full of extreme existential, cultural, and civilizational pessimism, atheism, and melancholy; he as well sees time and history as murky regions of decadence and corruption in which all hope is doomed to vanish. This philosophical stance seems to be in contradiction with Brzozowski's line of thinking, which, in brief, can be characterized as an expression of humanism and vitalism, the belief in the highest value of history, man, and his projects, and the possibility of progress. These are all characteristic features of the early, heroic version of modernity which is still unconscious of its own dark side.

The area in which I want to situate the comparison between Brzozowski and Cioran is the problem of modernity, or more precisely a modernity that has been deferred. The nations of East-Central Europe, which are situated spatially and temporarily on the margins of European modernity, have been experiencing this delay since the late nineteenth century and they have had to face the problems that arise from this. Cioran deals with such problems in his third book, Schimbarea la faţā a Romaniei (Transformation of Romania), published in 1936. I want to concentrate my attention on this book because, as far as I know, it has 
not been translated into Polish or English ${ }^{1}$ and it presents aspects of Cioran's thought that are relatively unknown. Brzozowski's ideas, which are much more popular and better known (at least in Poland), will serve here as a context. By comparing some parts of Brzozowski's and Cioran's philosophies, I also want to substantiate my thesis that the former defined a set of problems that successive Central European thinkers have had to solve or at least to deal with.

Cioran frequently made critical and ironic observations about his compatriots in a number of works, but he most fully confronts Romanian identity in Transformation of Romania. It should be noted that the character and ardour of this confrontation can be compared with Brzozowski's clash with Polish identity in Legenda Młodej Polski (The Legend of Young Poland). When writing their crucial texts, both Brzozowski and Cioran were young men at the respective ages of thirty-one and twenty-six. The historical, civilizational, and cultural contexts of these two works were set as confrontations with their respective "backward" countries during the inevitable process of modernization. However, the consequences of these clashes were the creation of modern nations and modern national cultures.

Some of the similarities between Brzozowski and Cioran can be found in their concepts of culture, their styles in critically analyzing these cultural phenomena, their visions of modernity, the way in which they treat history and the historical dimension of culture, and their rhetoric and the narrative roles that they assume as the speaking subjects of their works.

Even without getting into a detailed discussion of the authors' opinions concerning Polish and Romanian societies, it is easy to notice that both thinkers were pessimistic about the state of their societies, and they consequently deliver a thorough and total critique of the cultural forms that are created by them. Due to their backwardness and their inability to develop culture, these forms are responsible for the deep inertia in the Polish and Romanian societies. Brzozowski and Cioran seem to presume that culture is the expression of social consciousness which can either assist or hinder a society's needs and progress. They also share the conviction that Poland and Romania required a project that would be able to satisfy the needs of the modernizing societies in their times. Thus, both writers can be considered as representatives of Kulturkritik in a CentralEuropean form.

The problem of history is crucial in Cioran's remarks on the Romanian condition, as having no history, or existing on its margins; it is the biggest issue for the Romanian people. Getting into history through the conscious creation of it

1 A French translation entitled Transfiguration de la Roumanie was published in 2008 by L'Herne publishing house. 
then should be the country's greatest goal, or even an obsession. Cioran goes as far as to invent terms meant to accentuate Romania's lack of history in his use of, for example, "sub-history," "a-history" (63), "non-history" (78), and "historical dream" (63). He illustrates this lack by contrasting history to the other concepts that replace it. First, he opposes history to time and the past, stating that "the past of Romania is time without history" (49) so that time is just simple duration, change, and flux. Along with this, Cioran contrasts history with geography so that "Romania is geography, and not history" (57), which consequently places geography - the domination of a spatial dimension in its immutability, stability, and continuity being rooted in some defined place - over history. Finally, he sees the metaphysical, irrational idea of fate replacing history; he argues that "Romanians do not understand history, [instead] they substitute destiny for history" (94). Fate is opposed to history as a synonym of eternity, determinism, and a passive acceptance of destiny, which received its full expression in the famous folk ballad "Mioriţa." The idea of fate is also close to the "lyrical proximity of being" (74) in which it is possible to find the "ontologism" characteristic of the Romanian culture. This can be identified with the primacy of idle being over change and, generally, with a static concept of the world, nature, and life as stable, given, and pre-formed structures, or, as Cioran himself puts it, "the worship of created reality, which causes inertia and stagnation" (102).

There are at least four important features that are common to Cioran's and Brzozowski's philosophies of history. First, they are both convinced that history is the only realm in which the creative potential of humankind can be realized and, consequently, they claim that neither an individual nor a nation can exist outside of history. They also treat history in purely anthropological terms, and not in religious or providential ones ("Man can create only one condition that gives him a central position in history," 104). Brzozowski and Cioran additionally reject the idea of any given and pre-formed reality which they treat as an illusion and fiction, and thus they also reject the so-called "referential" concept of truth (i.e., truth seen as correspondence between cognitive structures and reality) treating it as a kind of illusion, based on the belief in the stable, unchanged essence of reality. Instead, they accept an "existential" idea of truth the essence of which lies in the creation of ever-new conditions and circumstances that serve life by stimulating progress and development. And lastly, both thinkers share the opinion that authentic history is the affirmation of coming into being and constant renewal. They also treat it as a domain of the will, an affir-

2 Emil Cioran, Schimbarea la faţă a României [Transformation of Romania] (Bucureşti: Humanitas, 1993), 41, 47 (henceforth, quotes from this book will be referenced directly in the main text). 
mation of a nation's existence and force, a domain in which a nation is fighting for recognition, and a process in which it gradually becomes self-conscious.

The problem of modernity is strictly connected with the problem of history. Cioran describes modernity on the two basic levels of civilization and philosophy. Both Cioran and Brzozowski use suggestive and clear contrasts in order to accentuate aspects of modernity that differentiate it from pre-modernity. Violent industrialization and urbanization are two fundamental phenomena that determine the character of modern culture. The city is a fully historical phenomenon: both knowledge and novel cultural forms are produced there, while on the other hand, the rural is the "suspension of history" because it is satisfied with spirituality and, in its simplicity and homogeneity, it can be no more than a biological reserve of the nation (118-120). Peasants have always existed at the peripheries of life; yet, the worker is situated at the very center of it- he can independently create life because he is aware of his significance and value (124). Subsequently, it is the worker who represents a new kind of humanity that determines the modern world's form, and mass culture created by the proletariat is a new kind of history (127). Peasants are reactionary, whereas the modern working masses are fighting for the self-consciousness they are deprived of. Their struggle takes form as a revolution which is then the crucial turning point of history that imposes its direction and substance on the simple and inert. According to Cioran, the evolution leading from the closed, integrated, and homogenous community to the shapeless mass that lacks any inner form and is based only on economic interest is degradation. Nevertheless, this process is historically necessary, it has an air of grandeur and fatalism which accentuates the tragic character of modernity (128).

Both Brzozowski and Cioran, as theorists of modernity, largely approve of urban civilization instead of traditional rural existence, which belongs to the past and is doomed to disappear. These traditional forms are represented by the Polish landed gentry in Brzozowski's thought and, in Cioran's opinion, their best incarnation is the Romanian peasantry. They unanimously see a new kind of humanity in the worker as creative and self-conscious (124). Modernity is, in their eyes, first of all a leap into history, life, and coming into being; it is also a creative impulse that liberates people from the passivity and inertia of the rural communities; and it is a chance to discover and develop the creative potential of humanity. But modernity is not only an opportunity, it is also a task that must be carried out by communities still deeply rooted in some form of pre-modernity. So, both thinkers seem to address their compatriots with an urgent and radical message: either we become modern or we perish. 
The foregoing similarities of Brzozowski and Cioran can be explained by the influence of the philosophy of life on both writers. In Romania, the best known and most influential partisan of this philosophy was Nae Ionescu, an intellectual patron and mentor of the entire generation of the young Romanian intellectuals born at the beginning of the twentieth century. Moreover, both Polish and Romanian thinkers can be recognized as disciples of Hegel. According to Brzozowski, Hegel first of all holds that the subject, made and formed in and by history, must finally dominate and control history. Cioran understands that for Hegel history is a process in the development of self-consciousness: "Hegel taught us a truth which became a cliché, the deepest sense of historical life is the realization of consciousness and the development of history is the development of consciousness" (7).

Although their styles differ, Brzozowski and Cioran adopt similar narrative roles and use many similar rhetorical devices. In his seminal essay on the discourse of the Legend of Young Poland, Michał Głowiński discerns three basic narrative roles of teacher, pamphleteer, and interpreter played by Brzozowski. ${ }^{3}$ Similar roles can be discerned in Cioran's Transformation of Romania. Both writers are sharp analysts and interpreters of contemporary culture and profound cultural critics. Moreover, they often serve as the educators of their societies, or even the prophets who uncover weaknesses, ruthlessly castigate vices, guide future development, and indicate the only means of salvation.

Many similarities can also be noticed in the style of both treatises. They are impetuous, accusatory and visionary, and full of passion and pathos. In the case of Cioran's book, even the title is a reference to the feast of the Transfiguration of Jesus ("Schimbarea la Faţa" in Romanian), which endows the entire discourse with a sublime and quasi-religious character. Both Brzozowski and Cioran use a very rich language, full of courageous generalities, effective formulas, and brilliant aphorisms - a mode of language which is very different from the reserved, transparent, and neutral style of a traditional philosophical paper. All of these features make these books philosophical essays, which was a very popular literary-philosophical genre at the turn of the twentieth century and during its first decades. Most important is the fact that all of these stylistic features and linguistic devices are not accidental, nor are they just an ornament of speech, but they are strictly connected with the essential features of thinking, in which description and critical assessment, analysis of the contemporary world, and projections of

3 Michał Głowiński, Ekspresja i empatia [Expression and empathy] (Kraków: Wydawnictwo Literackie, 1997), 290. 
the future are tightly interconnected. The language used by Brzozowski and Cioran is then a performative language, focused on changing reality.

\section{WORKS CITED}

Cioran, Emil. Schimbarea la faţă a României. Bucureşti: Humanitas, 1993.

—. Transfiguration de la Roumanie. Paris: L'Herne, 2008.

Głowiński, Michał. Ekspresja i empatia. Kraków: Wydawnictwo Literackie, 1997.

Kozicka, Dorota. “'Umysł w stanie nieustannego tworzenia'. O krytyce Stanisława Brzozowskiego jako akcie performatywnym." Teksty Drugie 5 (2011): 265-274.

4 Dorota Kozicka was the first to describe the performative aspects of Brzozowski's language in her essay “'Umysł w stanie nieustannego tworzenia'. O krytyce Stanisława Brzozowskiego jako akcie performatywnym" ["A mind in the state of incessant creation." On Stanisław Brzozowski's criticism as a performative act], Teksty Drugie 5 (2011). 